\title{
Measurement of National Education Standards: (Analysis of Achievement of Accreditation Results and Improvement Strategy)
}

\author{
Suryadi, Asep Suryana, Lia Laela Sarah, and Widiawati
}

\begin{abstract}
Setting standards in the education becomes a necessity in an effort to guarantee the implementation of quality education. In Indonesia, education standards are formulated in a law governing national education standards consisting of eight minimum standards that must be met. The research was a qualitative descriptive research with a case study method in senior high schools in Indonesia that studies the measurement of the achievement of national education standards from the aspects of obstacles encountered and their improvement strategies. Research data were collected through interviews, observations and documentation studies. The data were analyzed by data reduction, data presentation and conclusion drawing. The results of the study provide information that in general national education standards have been met, but in some aspects still need further improvement efforts. The efforts to improve can be done through participatory leadership, making standards compliance as a culture and building commitment.
\end{abstract}

Index Terms-Accreditation, leadership, national education standards, school culture, standard measurement.

\section{INTRODUCTION}

Globalization has increased economic competition within and between countries. Economic competitiveness is generally seen as a valid index for assessing a country's economic prosperity. In this case, to build economic prosperity, it can be done through the expansion and improvement of education. It is generally assumed that to improve economic competitiveness, citizens must obtain the knowledge, skills and attitudes obtained through education [1]. Developed nations must be supported by human resources who are resilient and resilient, intelligent, creative and have a good moral standards. Investment in education provides a guarantee for the nation to be more productive, because the accumulation of knowledge, skills, and attitudes and good morals, in turn will be able to improve the welfare of its people.

Furthermore, related to the level of economic prosperity with the availability of superior human resources, quality has become a critical and important issue, so that quality is a

Manuscript received September 23, 2019; revised March 29, 2020. This work was supported in part by Universitas Pendidikan Indonesia, Indonesia and High School of Laboratorium Universitas Pendidikan Indonesia, Indonesia.

Suryadi, Asep Suryana, and Widiawati are with Universitas Pendidikan Indonesia, Indonesia (e-mail: suryadi@upi.edu, doef@upi.edu, widiawati9110@upi.edu).

Lia Laela Sarah is with High School of Laboratorium Universitas Pendidikan Indonesia, Indonesia (e-mail: lialaesa@gmail.com). burden of duty for every product or service provider. In this case, one of the things that must be improved by educational institutions is the effectiveness of performance in the teaching and learning process and improvement in the quality of the institution. Therefore, every educational institution needs to build quality standardization to be achieved.

The quality of education is a classic problem that the Government always strives to improve. Although various efforts have been taken, the quality of education has not been realized optimally [2]

In the midst of this complex landscape of educational problems, the government established Government Regulation (PP) number 19 of 2005 concerning National Education Standards (SNP) and the National Education Standards Agency (BSNP). BSNP is an independent agency whose tasks to developing, monitoring the implementation and evaluation of the SNP. SNP aims to ensure the quality of national education in the intellectual life of the nation and shape the character and civilization of a dignified nation. Various government efforts were made to overcome the problems of education as part of efforts to improve the welfare of the community.

These efforts include: updating the national education system law (SISDIKNAS), updating the curriculum, increasing professionalism and teacher welfare, completing educational infrastructure, establishing and striving for national education standards. These efforts have shown a comprehensive step in improving the quality of education, but its implementation is not yet optimal

Standardization; basically is an effort to formulate the minimum criteria about various educational resources that must be met by the organizer and / or education unit in providing educational services, both in terms of learning material, learning process, graduate competency level, facilities, management, funding, and assessment education. If this can be realized, then this is the first time of this nation has standards in the administration of education, and at the same time is a reform in our education system. These standards will be the basis / reference in the planning, implementating and supervising the education throughout Indonesia, in order to realize quality national education. These standards will be developed by functionally independent bodies.

In reference to national standards, the government and regional governments will "fight" to make some efforts to guarantee quality; especially in the provision and / or facilities of educational resources, such as teachers, school buildings, books, teaching materials, financial and others.

Meanwhile, accreditation or assessment of the feasibility of programs and / or education units that refer to national 
standards will be spurred in order to be able to achieve significant activity targets. This accreditation will also be carried out by an independent body.

Accreditation and certification are very positive benchmarks in an effort to further improve the quality of schools, especially the quality variations achieved by school institutions are not evenly distributed. In the National Education System Law in Chapter I, Article 1, and paragraph 32 it is stated that accreditation is an activity of evaluating the feasibility of a program in an education unit based on predetermined criteria. Certification (2) as a sign of authority for someone describes the competencies that must be possessed.

Achieving school quality through school accreditation activities is directed at the following: 1) the accreditation process leads to improving school quality, 2) seeing and obtaining an actual picture of school performance, 3 ) as a tool for fostering, developing, and improving the quality of education in schools ,4) the feasibility of the school in its administration and services, 5) a comprehensive picture for the community about the level of the school where their children are located with other schools [3].

The purpose of setting national education standards is to ensure the quality of national education in the intellectual life of the nation and shape the character and civilization of a dignified nation. In this regard, the education quality assurance and quality control are in line with national education standards and sustainability in accordance with the ever-changing demands at the national, regional and international levels, accreditation evaluation is applied. and certification.

According to Government Regulation Number 19 of 2005 concerning National Education Standards, the implementation of education is said to be of good quality if it is carried out in accordance with the specified national education standards. In this case there are eight educational standards, they are: content standards, process standards, graduate competency standards, teacher and education staff standards, facilities and infrastructure standards, management standards, financing standards, and education assessment standards. The eight standards are interrelated to support the implementation of a quality learning process. Thus, it can be said that the quality of an education lies in the quality of learning.

Considering the eight national education standards are minimum criteria with many indicators that must be fulfilled by each education unit, the achievement of each of these criteria must be specifically described so that points of weakness and weaknesses can be identified in certain indicators.

Based on the description above, the formulation of the problem of this research are a) How to map the achievements of each national standard of Education in the Laboratory High School and b) What are the recommendations for improvement for achieving the national standards of Education?

The urgency of this research was carried out because there were two main things. First; the results of this study contributed to the improvement of the learning process and education in the Laboratory Senior High School, especially related to the achievement of the National Education Standards. Second; practically this research provides a basis in empirical practice in order to map the achievements of each national education standard. The study of measuring the achievement of national education standards is a very important thing in the effort to improve the quality and increase the quality of an education unit.

\section{METHODOLOGY}

This research is a qualitative research with case study method by analyzing the level of achievement of national education standards in terms of strengths and weaknesses and presenting recommendations for improvement.

This study analyzes eight national education standards in Indonesia, they are 1) content standards, 2) process standards, 3) graduate competency standards, 4) educators and education personnel standards, 5) facilities and infrastructure standards, 6) management standards, 7) standards financing and 8) valuation standards.

This research was conducted at the Laboratory of High School in Universitas Pendidikan Indonesia (SMA Laboratorium UPI). The research informants consisted of school principals, vice principals and eight teachers who were involved in the process of meeting standards related to the implementation of school accreditation.

Research data was collected through interviews, observations and documentation study. Interviews were conducted with school principals, vice principals and teachers to find out the level of achievement of standards and the constraints and efforts made to achieve national education standards. Observation was carried out to see how the process of achieving standards was carried out while the documentation study was carried out to see documents relating to the achievement of national education standards as physical evidence. Research data were analyzed by data reduction, data presentation and conclusion drawing.

\section{RESUlTS AND DISCUSSION}

\section{A. Result}

Based on the results of the study, information was obtained that overall the UPI Laboratory High School was able to reach national education standards. The ability to achieve national education standards is evidenced by the acquisition of accreditation A from the National High School Accreditation Board (BAN-SM). This illustrates that every item that became the minimum standard set in the SNP was able to be fulfilled by the UPI Laboratory High School as a whole. Although as a whole the UPI Laboratory High School is able to meet these national standards, but there are still items in the school content data that have $\mathrm{B}$ and $\mathrm{C}$ grades, and some even have $\mathrm{E}$ grades. For more spesific information, it can be seen on Table I below.

One form of assessment of the achievement of national education standards in Indonesia is by accreditation. The results showed that in this case, the high school laboratory carried out the process of preparing all the documents needed in the implementation of accreditation within a period of two 
months and some were carried out like "sangkuriang", done quickly in a very short time.

\begin{tabular}{|c|c|c|c|c|c|}
\hline \multirow[b]{2}{*}{ No } & \multirow{2}{*}{$\begin{array}{l}\text { Education } \\
\text { Standard }\end{array}$} & \multirow{2}{*}{$\begin{array}{l}\text { Number } \\
\text { of items }\end{array}$} & \multicolumn{3}{|c|}{ Result } \\
\hline & & & Grade & $\begin{array}{l}\text { Number } \\
\text { of items }\end{array}$ & $\%$ \\
\hline \multirow{5}{*}{1} & \multirow{5}{*}{$\begin{array}{l}\text { content } \\
\text { standards }\end{array}$} & \multirow{5}{*}{9} & A & 9 & $100 \%$ \\
\hline & & & $\mathrm{B}$ & 0 & 0 \\
\hline & & & $\mathrm{C}$ & 0 & 0 \\
\hline & & & $\mathrm{D}$ & 0 & 0 \\
\hline & & & $\mathrm{E}$ & 0 & 0 \\
\hline \multirow{5}{*}{2} & \multirow{5}{*}{$\begin{array}{c}\text { process } \\
\text { standards }\end{array}$} & \multirow{5}{*}{21} & $\mathrm{~A}$ & 21 & $100 \%$ \\
\hline & & & $\mathrm{B}$ & 0 & 0 \\
\hline & & & $\mathrm{C}$ & 0 & 0 \\
\hline & & & $\mathrm{D}$ & 0 & 0 \\
\hline & & & $\mathrm{E}$ & 0 & 0 \\
\hline \multirow{5}{*}{3} & \multirow{5}{*}{$\begin{array}{c}\text { graduate } \\
\text { competency } \\
\text { standard }\end{array}$} & \multirow{5}{*}{7} & A & 7 & 100,00 \\
\hline & & & $\mathrm{B}$ & 0 & 0 \\
\hline & & & $\mathrm{C}$ & 0 & 0 \\
\hline & & & $\mathrm{D}$ & 0 & 0 \\
\hline & & & $\mathrm{E}$ & 0 & 0 \\
\hline \multirow{5}{*}{4} & \multirow{5}{*}{$\begin{array}{l}\text { educators } \\
\quad \text { and } \\
\text { education } \\
\text { personnel } \\
\text { standards }\end{array}$} & \multirow{5}{*}{19} & A & 13 & 68,42 \\
\hline & & & $\mathrm{B}$ & 2 & 10,53 \\
\hline & & & $\mathrm{C}$ & 2 & 10,53 \\
\hline & & & $\mathrm{D}$ & 0 & 0,00 \\
\hline & & & $\mathrm{E}$ & 2 & 10,53 \\
\hline \multirow{5}{*}{5} & \multirow{5}{*}{$\begin{array}{c}\text { facilities and } \\
\text { infrastructur } \\
\text { e standards }\end{array}$} & \multirow{5}{*}{28} & $\mathrm{~A}$ & 24 & 85,71 \\
\hline & & & $\mathrm{B}$ & 3 & 10,71 \\
\hline & & & $\mathrm{C}$ & 0 & 0,00 \\
\hline & & & $\mathrm{D}$ & 0 & 0,00 \\
\hline & & & $\mathrm{E}$ & 1 & 3,57 \\
\hline \multirow{5}{*}{6} & \multirow{5}{*}{$\begin{array}{c}\text { management } \\
\text { standards }\end{array}$} & \multirow{5}{*}{16} & $\mathrm{~A}$ & 16 & 100 \\
\hline & & & $\mathrm{B}$ & & 0 \\
\hline & & & $\mathrm{C}$ & & 0 \\
\hline & & & $\mathrm{D}$ & & 0 \\
\hline & & & $\mathrm{E}$ & & 0 \\
\hline \multirow{5}{*}{7} & \multirow{5}{*}{$\begin{array}{l}\text { Financing } \\
\text { standards }\end{array}$} & \multirow{5}{*}{16} & A & 16 & 100 \\
\hline & & & $\mathrm{B}$ & & 0 \\
\hline & & & $\mathrm{C}$ & & 0 \\
\hline & & & $\mathrm{D}$ & & 0 \\
\hline & & & $\mathrm{E}$ & & 0 \\
\hline & & & A & 12 & 100 \\
\hline & & & $\mathrm{B}$ & & 0 \\
\hline 8 & $\begin{array}{c}\text { Evaluation } \\
\text { standards }\end{array}$ & 12 & $\mathrm{C}$ & & 0 \\
\hline & & & $\mathrm{D}$ & & 0 \\
\hline & & & $\mathrm{E}$ & & 0 \\
\hline
\end{tabular}

First, the information showing the content standard, all items that are assessed in the content standard of education have received an A, 100\%. That is, the content standards can be met in accordance with established standards. Curriculum standards have been well met. Although it has been well fulfilled, but there are things that still need to be evaluated in terms of content standards, the suitability of the learning implementation plan is still in the administrative level, meaning that limited to the supply of documents has not touched at the implementation stage in the classroom.

Second, the process standard. All grading points in the process standard have obtained an A, $100 \%$. So that it can be interpreted that the items that are assessed in the process standard have been fulfilled well. However, in the standard process, there are some difficulties experienced by the responsible team, namely the difficulty in collecting syllabi from the teacher. Syllabus is collected in one month. The syllabus should be collected at the beginning of every year of the syllabus from each teacher. In addition, other difficulties also occur when the assessor assesses the learning implementation plan made by the teacher. In this case, there are differences in the format of the learning implementation plan between the assessors and those made by the Laboratory High School. Furthermore, in the implementation of supervision. The supervision program conducted by the principal along with the follow-up received the attention of the assessors. In this case, supervision activities and follow-up supervision results must be made in a more complete format.

Third, graduate competency standards. The results of the study of the items on the graduation standard indicate that the Laboratory High School is able to meet all the items that become the assessment items in the graduation standard by obtaining an A on all items, 100\% reached. However, based on the assessment of the assessors, the Laboratory High School still needs to increase its graduates to continue on to college. In addition, based on the results of the focus group discussion, the responsible team revealed several difficulties associated with meeting this graduation standard. Among them are related to the provision of school activities or program documents. According to the ideal conditions, every activity / program carried out by the school such as the literacy program, the school hygiene competition must have a document that is a proposal and an activity report. However, in reality, there are some activities / programs in SMA Laboratorium which have activity proposals but do not have activity reports and vice versa. This means that the activities / programs carried out by schools are still not $100 \%$ well documented. In addition, notes about student achievement are also not well documented. So, to overcome this, the team responsible for passing standards creates programs and activity reports by collaborating with extracurricular activities and documenting activities in physical form.

Fourth, the standard of educators and education personnel. The standards of educators and education personnel in Laboratory High Schools need special attention. This is because, based on the accreditation point assessment, of the 19 standards assessed, as many as 13 items received a value of $\mathrm{A}$, the remaining 2 items obtained a value of $\mathrm{B}$, a value of 2 points and a value of 2 points $E$. Constraints faced in this case are

1) The ratio between $B K$ teachers and the number of students according to the laboratory high school still does not comply with the provisions (1 BK teacher serves a maximum of 150 students). While the real conditions in SMA Laboratorium are 1 BK teacher serving 150-200 students (value B). That is, the Laboratory High School still lacks one BK teacher.

2) Relating to the criteria that must be met by the principal. 
Of the 9 criteria set, the laboratory high school successfully fulfilled 7-8 criteria (value B).

3) Laboratory high school teachers who have educational certificates still range from $56 \%-70 \%$ have educator certificates (value C). Meanwhile, in order to obtain an A, $86 \%-100 \%$ of teachers have an educator certificate. While the Laboratory High School teachers who have not been certified are still above $20 \%$.

4) Laboratory High School still does not have administrative staff in accordance with the requirements set in the standards of educators and educational staff. In this case, the Laboratory High School received a $\mathrm{C}$ grade. The administrative staff of the Laboratory High School had an undergraduate education and had a minimum of 4 years experience. However, the problem that remained an obstacle was that the Head of Administrative Laboratory or administrative staff was still not certified.

5) The Laboratory High School does not yet have library staff so for this item an E grade is obtained.

6) Items that get other E values are related to the laboratory assistant. In this case, the Laboratory High School still does not have a laboratory assistant.

Fifth, the standard of facilities and infrastructure. Overall, the standard facilities for Laboratory High School infrastructure have met the established standards. Of the 28 items that are required, 24 of them have obtained an A. The remaining 3 items have a value of $\mathrm{B}$ and one item has an value of $\mathrm{E}$. Things that still need attention for high school laboratories are related to laboratories, both biology, chemistry and physics. Each of these laboratories gets a value of $\mathrm{B}$. This is because the laboratory is still united in one room. Meanwhile, language laboratories received an E because they were only able to meet less than 3 specified requirements.

Sixth, management standards. Overall, $100 \%$ of the items assessed in management standards have received an A. This means that all existing requirements have been able to be fulfilled by the Laboratory High School. However, based on the results of the FGD, information was obtained that the vision and mission of the school still needed to be reviewed at least once a year and in the process of formulating the vision and mission that still did not involve all school stakeholders. In practice, the process of formulating the vision and mission at the UPI Laboratory High School is still not used as a program. So that the vision formulation mechanism is sometimes done by not involving all relevant parties. In this case too, the minutes and minutes of the process of formulating the vision and mission are also not well organized. In addition, there is still a dual system of duties in the management of several school activities such as in the field of dual student assignments with the extracurricular field.

Seventh, financing standards. As a whole, the item of standard item of financing that becomes an evaluation in accreditation has obtained an A. This means that the Laboratory High School has fulfilled all the requirements of the financing standard starting from the existence of a work plan and budget to the budget accountability report. Even so, the school still raised obstacles related to funding standards, namely the existence of differences in the format of the assessors and those made by the school. So the format of the work plan and school budget is different from the assessor's expectations.

The last is the assessment standard. Laboratory High School $100 \%$ has been able to meet the overall assessment standards that have been set. All items used as standards have been achieved with an A. However, in this case there are still obstacles faced by the Laboratory High School, which still needs to document authentic assessment in order to be more complete. Because in this case, some assessments are still done manually and not yet digital. For this reason, a management information system is needed.

\section{B. Discussion}

From the description above, it can be concluded that the thing that becomes a major challenge that must be met by the Laboratory High School is related to 1) the standards of educators and education personnel and 2) the standard of facilities and infrastructure.

Educators and education personnel are the main key in the practice of providing education. Especially educators, as the obstacle faced by the Laboratory High School that educators who obtained certification were still around $56 \%-70 \%$. That is, there are still $30 \%$ of the teachers who still need to be certified. Certification is important and influences student achievement [4]. Some previous studies also show that teacher education and certification influence student success in learning [5]-[7]. In addition, certified teachers generally have certain competencies as required and this will show the credibility of a teacher. The level of credibility of a teacher will also affect students [8]. Therefore, the High School Laboratory must provide support to teachers for the certification process with the existence of mechanisms and support from the foundation. In connection with education staff, it is necessary to provide educational staff, both administrative staff, laboratory assistants and librarians and counseling guidance teachers through addition and inclusion in the school work plan and in collaboration with UPI laboratory foundations.

Furthermore, facilities and infrastructure are important things for schools to complete. The availability of school facilities will have an impact on learning [9]. The existence of facilities and infrastructure will greatly influence the school climate and the success of students in learning [10]. Therefore, related to the condition of facilities and infrastructure at the UPI Laboratory High School, aspects of facilities and infrastructure have also become a major work for the Laboratory High School, particularly in relation to laboratories which are currently still in one room (labor biology, chemistry, and physics and labor language). It is not easy to conduct separate laboratories, because the procurement of laboratories is not only limited to the availability of space, but also in terms of the budget and funds owned by schools. Therefore, the solution for the procurement of this laboratory is to propose a budget to hold each laboratory and the provision of space. Indeed, for this it requires considerable time and funds.

Based on several obstacles encountered in meeting the above national education standards, the main strategy in the effort to increase the fulfillment of national standards is the need for leadership. 
Leadership is a process where other people are influenced to understand and agree on what must be done and how everything must be effectively and collaboratively implemented to achieve a goal [11]. Effective leadership is at the core of continuing to improve the quality of schools [12]. One effort is to implement collaborative leadership. Collaborative leadership prioritizes collaboration between principals, educators and education personnel in achieving school goals [13]. The results of research on collaborative leadership show that collaborative leadership can have an influence on the development and improvement of schools [14]. With the leadership that prioritizes this collaboration, of course, the fulfillment of national education standards can be done together with the expectation that the fulfillment of these standards is not the responsibility of one person, but the responsibility of all school members.

Aside from collaborative leadership, making compliance standards as a culture also needs to be instilled in all school stakeholders, so that the document supply system can be well documented and standards and quality can be achieved without the need for a "sangkuriang" system so that school customer satisfaction can be met from the start. If a fulfillment of educational standards has been made as a culture, then all kinds of activities that lead to the fulfillment of standards are no longer limited to the provision of administrative documents, but have become something that is internalized within every school stakeholder, so that difficulties such as the document collection process certain documents can be minimized. As we know that, culture is something that has been internalized in a person so that it becomes a habit. This cultural development is also the task of the principal's leadership. As described in some literature that principals are facilitators for building school culture [15], [16]. Strengthening the leadership of principals is very important because the leadership will determine a good organizational culture in the school [17].

Furthermore, building commitments in school members related to national education standards needs to be strongly embedded. Without commitment, all things that have been designed will be of no use [18]. In the development of quality assurance, one of which is done through the fulfillment of national education standards requires a professional attitude that is the attitude of those who are fully committed to their duties towards quality excellence [19].

\section{CONCLUSION}

High School Laboratories in general have met national education standards as evidenced by the accreditation program A from the national secondary school accreditation Board. Although as a whole has met the standards, but in some aspect, especially related to the standards of educators and education staff, there are still aspects that need to be improved. In addition, there is still a tendency that on several sides, the fulfillment of national education standards is still at the administrative level. The effort to improve it is certainly a joint task for all school members. The application of participatory leadership can be applied because this leadership makes collaboration as one way to achieve school goals. Building a quality culture is something that must be done with full awareness and commitment in the school community.

\section{CONFLICT OF INTEREST}

We declare that there is no conflict of interest.

\section{AUTHOR CONTRIBUTIONS}

In this paper, the first author is the lead researcher. The first author is in charge of directing the course of the study. Whereas the second author is the research representative. The first author and the second author play a role in determining the title of the study, determining the main problems of the study and preparing research proposals and research instruments and guiding in the process of data writing research report. The third author acts as a field data collector and data analisys. The fourth author acts as a team that helps in preparing proposals, processing data fields and compiling reports on research results. The final version of the paper was discussed and arranged together. All authors have agreed to the final version.

\section{REFERENCES}

[1] P. Sahlberg, "Education reform for raising economic competitiveness," Journal of Educational Change, vol. 7, no. 4, pp. 259-287, 2006.

[2] H. Muchtar, "Penerapan Penilaian Autentik dalam Upaya Peningkatan Mutu Pendidikan," Jurnal Pendidikan Penabur, vol. 14, no. 9, pp. 68-76, 2010.

[3] B. A. N. S. Menengah, Ringkasan Eksekutif Capaian Dan Analisis Pemenuhan Standar Nasional Pendidikan (SNP) Hasil Akreditasi Sekolah Dan Madrasah Tahun, 2018.

[4] D. D. Goldhaber and D. J. Brewer, "Does teacher certification matter? High school teacher certification status and student achievement," Educational Evaluation and Policy Analysis, vol. 22, no. 2, pp. 129-145, 2000.

[5] L. Darling-Hammond, "Reforming teacher preparation and licensing: Debating the evidence," Teachers College Record, vol. 102, no. 1, pp. 28-56, 2000.

[6] P. P. Hawk, C. R. Coble, and M. Swanson, "Certification: It does matter," Journal of Teacher Education, vol. 36, no. 3, pp. 13-15, 1985.

[7] R. P. Strauss and E. A. Sawyer, "Some new evidence on teacher and student competencies," Economics of Education Review, vol. 5, no. 1, pp. 41-48, 1986.

[8] J. J. Teven, "Teacher caring and classroom behavior: Relationships with student affect and perceptions of teacher competence and trustworthiness," Communication Quarterly, vol. 55, no. 4, pp. 433-450, 2007.

[9] M. Schneider, Do School Facilities Affect Academic Outcomes? 2002.

[10] C. Uline and M. Tschannen-Moran, "The walls speak: The interplay of quality facilities, school climate, and student achievement," Journal of Educational Administration, vol. 46, no. 1, pp. 55-73, 2008.

[11] G. Yukl, Leadership in Organizations, Englewood Cliffs, NJ: Prentice-Hall, 2002.

[12] A. Raman et al., "Relationship between principals' transformational leadership style and secondary school teachers' commitment," Asian Social Science, vol. 11, no. 15, pp. 221-228, 2015.

[13] A. A. Shaharbi. (2010). Leadership behaviour and practices of a head teacher in an excellent school. [Online]. Available: http://library.oum.edu.my/repository/557/1/Leadership_behaviour.pdf

[14] R. H. Heck and P. Hallinger, "Collaborative leadership effects on school improvement: Integrating unidirectional- and reciprocal-effects models," The Elementary School Journal, vol. 111, no. 2, pp. 226-252, 2010.

[15] K. Leithwood and D. Jantzi, "Transformational leadership: How principals can help reform school cultures," School Effectiveness and School Improvement, vol. 1, no. 4, pp. 249- 280, 1990.

[16] N. L. Waldron and J. McLeskey, "Establishing a collaborative school culture through comprehensive school reform," Journal of Educational and Psychological Consultation, vol. 20, no, 1, pp. 58-74, 2010.

[17] I. Arifin and A. Taufiq, "Islamic crash course as a leadership strategy of school principals in strengthening school organizational culture," SAGE Open, pp. 1-10, 2018.

[18] I. Arifin et al., SAGE Open, doi: 10.1177/2158244018799849. 
[19] Lewis, Quality Assurance in Teaching, Baston: Longman, 1995.

Copyright (C) 2020 by the authors. This is an open access article distributed under the Creative Commons Attribution License which permits unrestricted use, distribution, and reproduction in any medium, provided the original work is properly cited (CC BY 4.0).

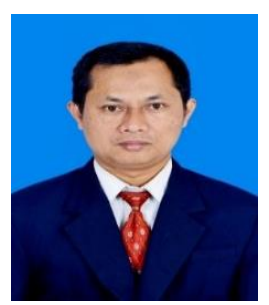

Suryadi was born in Bandung, on July 29, 1968. The author educational background are: bachelor degree with the fieldin Educational Administration IKIP Bandung Indonesia (year 1995); magister of Educational Administration in Universitas Pendidikan Indonesia, Bandung Indonesia 2008; the doctoral of Educational Administration in Universitas Pendidikan Indonesia, Bandung, Indonesia, 2017.

Now, he is a lecturer at the Department of educational administration in UPI Bandung and also serves as chairman of the Department. In addition, he is the head of the quality control unit at faculty of education in UPI Bandung. Some papers that he has written are 1) Pengaruh Kapasitas Guru dan Manajemen Pengetahuan terhadap Kinerja Guru published in Pedagogia Jurnal Ilmu Pendidikan Volume 4, Nomor 1, April 2017, ISSN: 1693-5276, page $573-$ 582,2 ) Model Penilaian Kinerja (Performance Appraisal) Kepala Sekolah menengah Pertama Negeri di Kabupaten Bandung Barat published in jurnal Pedagogia Jurnal Ilmu Pendidikan Volume 3, Number 3 December 2016, ISSN: 1693-5276, page 387 - 395.

He also wrote some books, including: 1) Manajemen Mutu Pendidikan Berbasis Sekolah (Bandung, Sarana Panca Karya Bandung, 2009), 2) Manajemen Pendidikan (Bandung, Alfabeta, 2009) dan 3) Sistem Informasi Pendidikan, Konsep-Teori dan Aplikasi (Bandung, Sarana Panca Karya, 2009). He is interested in the field of education administration studies.

Dr. Suryadi, M.Pd. is a member of ISMAPI (Ikatan Sarjana Manajemen Administrasi Pendidikan) (2009-until now), Asesor LPPKS (2015- until now), DKM Nurul Asri (2010- until now). He earned the award as Service Provider USAID PRIORITAS dari USAID PRIORITAS in 2017.

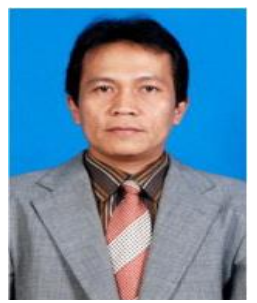

Asep Suryana was born in Sumedang, on March 21, 1972. The author educational background are: bachelor degree of field of educational administration IKIP Bandung, Indonesia, 1995; the magister of educational Administration Universitas Pendidikan Indonesia, Bandung, Indonesia ， 2004; the doctoral of Educational Administration in Universitas Pendidikan Indonesia, Bandung, Indonesia 2010.

$\mathrm{He}$ is a lecturer at Department of Educational Administration in UPI Bandung since 1999 until now. He is also a member of the UPI Strategic Planning Team (2016) and the UNIS Strategic Planning Team (2016). He became chairman of the Compilers of the Educational Administration Curriculum in 2017-2018. Now he serves as BPP Treasurer in the Senior High School Laboratory of UPI Bandung and a member of the UPI FIP academic senate.

He wrote some books, they are 1) Implementasi Perencanan Strategis Di PT (Bandung, Indonesia, Alfabeta, 2018), 2) Value Based Leadership (Indonesia, Nurani Press, 2013) dan 3) efektivitas Pengembangan Kinerja (Indonesia, Nurani Press, 2013).

Some paper that he wrote are 1) Management readiness and Organizational Behavior of Indonesian Teacher Education Institutions in Organizational
Culture and Behavioral Aspects (Procedding, ISBN: 978-602-60731-2-9) year 2017, 2) Manajemen Capacity Bulding Tenaga Admnistrasi Sekolah (Jurnal Ilmu Pendidikan, Issn 1693-5276) year 2017 dan 3) Development of Value-Based Leadership: Model in Quality Culture Improvement on Primary Schools (Procedding, Atlantis Press, 2016). He is interested in research in leadership, policy and education management.

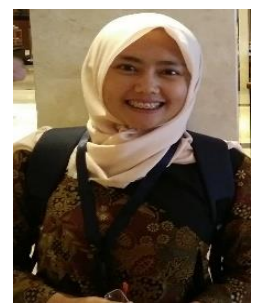

Lia Laela Sarah was born in Garut, on May 29, 1983. Her educational background is: bachelor of physical education in Universitas Pendidikan Indonesia, Bandung, Indonesia 2005; the magister of media technology in Institut Teknologi Bandung, Indonesia 2012.

She is a teacher and a deputy headmaster at senior high school UPI Bandung Laboratory.

Some scientific articles that she has written are: 1) Analysis of Students Interaction on Technology Based Conceptual Change Text in Physics Classroom (Bandung, 2018), 2) The Implementation of Technology Enhanced Conceptual Change Texts on Student's Activity and Understanding of Electric Force (Malaysia, 2017), 3) Pengembangan Technology Enhance Worksheet Pada Konsep Interferensi Cahaya (Yogyakarta, 2017), 4) Improving Students Sciencetific Practicess Using Technology Enhance Worksheet Inquiry on Static Electricity (Bali, 2018). Buku yang pernah ditulisnya adalah Memaknai Osilasi Pegas (Chapter of Book Bercermin dari Pembelajaran) (Rizqi Press, Indoensia, 2016).

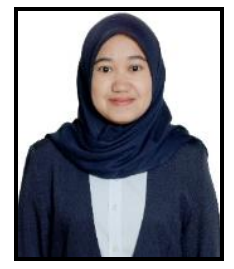

Widiawati was born in Bukittinggi on October 02, 1991.

Her educational background are: bachelor of field educational administrastion in Universitas Negeri Padang, West Sumatera, Indonesia 2015; magister of educational aminidtration in Universitas Pendidikan Indonesia, Bandung, west Java, Indonesia 2019

She was an awardee of Bidikmisi scholarship year 2011-2015 and an awardee of Educational Fund Management Institution (LPDP) year 2017-2019. The author received an award as the best graduate of the 2015 bachelor's degree and a 2019 master's degree. The writer is a fresh graduate and is now a research assistant and assistant lecturer at UPI Bandung's education administration.

Some scientifis papers that she wrote are 1) Hubungan kepemimpinan transformasional dan budaya organisasi pada Sekolah Menengah Kejuruan Swasta di Kota Padang (thesis), 2) Keunggulan Bersaing dalam sistem penjaminan mutu internal fakultas di Universitas Pendidikan Indonesia (thesis), 3) The Implementation of Strategic Management in Developing School (prosiding Atlantis press), 4) School Organizational Culture And The Way To Improve It: A case Study (prosiding ISBN), 5) Implementasi Sistem Manajemen Mutu ISO (prosiding ISBN).

Widiawati, M.Pd. be a speaker at international and national conferences, they are: The 2nd International Conference on Research of Educational Administration and Management (ICREAM 2018), National Conference on education with the thema Kepemimpinan Pendidikan di Era 4.0, Bandung, 30th October 2018. National Conference on education with the thema "Kepemimpinan dan Budaya Mutu Pendidikan Pada era Revolusi Industri 4.0". Bandung, 18th Desember 2018, Join Conference at Seoul Nasional University at 30th April 2019 in Seoul, The 3rd International Conference on Research of Educational Administration and Management (ICREAM 2019), Bandung, 17th July 2019. 